\title{
Antibacterial effectiveness of drug combinations with calcium hydroxide in apical
}

\section{periodontitis: A systematic review}

\author{
Eficácia antimicrobiana de associações medicamentosas com o hidróxido de cálcio na periodontite \\ apical: Revisão sistemática
}

Eficacia antibacteriana de las combinaciones de fármacos con hidróxido de calcio en la

periodontitis apical: Una revisión sistemática

Received: 04/02/2021 | Reviewed: 04/10/2021 | Accept: 04/12/2021 | Published: 04/23/2021

\author{
Christianne Velozo \\ ORCID: https://orcid.org/0000-0001-9651-3043 \\ University of Pernambuco, Brazil \\ E-mail: chris_velozo@hotmail.com \\ Cleidiel Aparecido Araújo Lemos \\ ORCID: https://orcid.org/0000-0001-8273-489X \\ University of Juiz de Fora, Brazil \\ E-mail: cleidiel@gmail.com \\ Diana Santana de Albuquerque \\ ORCID: https://orcid.org/0000-0002-7897-2489 \\ University of Pernambuco, Brazil \\ E-mail: dianaendodontia@gmail.com \\ Belmiro Cavalcante do Egito Vasconcelos \\ ORCID: https://orcid.org/0000-0002-6515-1489 \\ University of Pernambuco, Brazil \\ E-mail: belmiro.vasconcelos@upe.br \\ Sandra Lúcia Dantas Moraes \\ ORCID: https://orcid.org/0000-0002-3154-5092 \\ University of Pernambuco, Brazil \\ E-mail: sandra.moraes@upe.br \\ Eduardo Piza Pellizzer \\ ORCID: https://orcid.org/0000-0003-0670-5004 \\ Paulista University, Brazil \\ E-mail: ed.pl@uol.com.br
}

\begin{abstract}
The aim of this systematic review was to compare the clinical performance of calcium hydroxide $(\mathrm{Ca}(\mathrm{OH}) 2)$ as an intracanal medicament alone or combined with other antimicrobial agents. The PICO question was "Is the antibacterial effectiveness of calcium hydroxide paste as an intracanal medication combined with other drugs greater than that of calcium hydroxide paste alone in apical periodontitis?" The study was carried out according PRISMA guidelines and is registered in PROSPERO (CRD42020205741). Searches were performed in the PubMed/MEDLINE, Web of Science and Cochrane databases without publication date restrictions. Inclusion: randomized clinical trials, non-randomized intervention studies, studies including a minimum of 10 patients, studies comparing the use of $\mathrm{Ca}(\mathrm{OH}) 2$ alone and in combination with other compounds, studies evaluating primary and permanent teeth with apical periodontitis, and studies including teeth not submitted to retreatment. The Cochrane riskof-bias tool for randomized clinical trials (RoB 2.0) was used to assess the internal validity (risk of bias) of the included studies. A total of 986 articles were retrieved and 12 randomized clinical trials were selected, totaling 499 patients included in the studies. The effectiveness of $\mathrm{Ca}(\mathrm{OH}) 2$ plus chlorhexidine was similar to that of $\mathrm{Ca}(\mathrm{OH}) 2$ alone in eight articles, while a better antibacterial effect was reported in three studies. The combination with ciprofloxacin was more effective than the use of $\mathrm{Ca}(\mathrm{OH}) 2$ alone in the only study that tested this antibiotic. In teeth with asymptomatic apical periodontitis, the effectiveness of the combination of antimicrobial agents with $\mathrm{Ca}(\mathrm{OH}) 2$ was similar to that of $\mathrm{Ca}(\mathrm{OH}) 2$ alone.
\end{abstract}

Keywords: Calcium hydroxide; Apical periodontitis; Antibacterial effectiveness; Systematic review.

\section{Resumo}

O objetivo desta revisão sistemática foi comparar o desempenho clínico do hidróxido de cálcio $(\mathrm{Ca}(\mathrm{OH}) 2)$ como um medicamento intracanal sozinho ou combinado com agentes antimicrobianos. A pergunta do PICO era "A eficácia antibacteriana da pasta de hidróxido de cálcio como medicamento intracanal combinado com outras drogas é maior do 
que a da pasta de hidróxido de cálcio sozinha na periodontite apical?" O estudo foi realizado de acordo com as diretrizes PRISMA e registrado no PROSPERO (CRD42020205741). As pesquisas foram realizadas nas bases de dados PubMed / MEDLINE, Web of Science e Cochrane sem restrições de data de publicação. Inclusão: ensaios clínicos randomizados, estudos de intervenção não randomizados, estudos com mínimo de 10 pacientes, estudos comparando o uso de $\mathrm{Ca}(\mathrm{OH}) 2$ sozinho e combinação com outros compostos, estudos avaliando dentes decíduos e permanentes com periodontite apical e estudos incluindo dentes não submetidos a retratamento. A ferramenta de risco de viés Cochrane para ensaios clínicos randomizados (RoB 2.0) foi usada para avaliar a validade interna dos estudos incluídos. Um total de 986 artigos foram recuperados e 12 ensaios clínicos randomizados selecionados, totalizando 499 pacientes incluídos nos estudos. A eficácia do $\mathrm{Ca}(\mathrm{OH}) 2$ mais clorexidina foi semelhante ao $\mathrm{Ca}(\mathrm{OH}) 2$ sozinho em oito artigos, enquanto um melhor efeito antibacteriano foi relatado em três estudos. A combinação com ciprofloxacino foi mais eficaz do que o uso de $\mathrm{Ca}(\mathrm{OH}) 2$ sozinho no único estudo que testou esse antibiótico. Na periodontite apical assintomática, a eficácia da combinação de agentes antimicrobianos com $\mathrm{Ca}(\mathrm{OH}) 2$ foi semelhante à do $\mathrm{Ca}(\mathrm{OH}) 2$ sozinho.

Palavras-chave: Hidróxido de cálcio; Periodontite apical; Eficácia antibacteriana; Revisão sistemática.

\section{Resumen}

El objetivo de esta revisión sistemática fue comparar el rendimiento clínico del hidróxido de calcio $(\mathrm{Ca}(\mathrm{OH}) 2)$ como medicamento intracanal solo o combinado con otros agentes antimicrobianos. La pregunta de PICO fue "Es la eficacia antibacteriana de la pasta de hidróxido de calcio como medicamento intracanal combinado con otros fármacos mayor que la de la pasta de hidróxido de calcio sola en la periodontitis apical?" El estudio se realizó según las directrices PRISMA y está registrado en PROSPERO (CRD42020205741). Las búsquedas se realizaron en las bases de datos PubMed / MEDLINE, Web of Science y Cochrane sin restricciones de fecha de publicación. Inclusión: ensayos clínicos aleatorizados, estudios de intervención no aleatorizados, estudios que incluyan un mínimo de 10 pacientes, estudios que comparen el uso de $\mathrm{Ca}(\mathrm{OH}) 2$ solo y en combinación con otros compuestos, estudios que evalúen dientes primarios y permanentes con periodontitis apical y estudios. incluidos los dientes no sometidos a retratamiento. Se utilizó la herramienta Cochrane de riesgo de sesgo para ensayos clínicos aleatorios (RoB 2.0) para evaluar la validez interna (riesgo de sesgo) de los estudios incluidos. Se recuperaron un total de 986 artículos y se seleccionaron 12 ensayos clínicos aleatorizados, con un total de 499 pacientes incluidos en los estudios. La eficacia del $\mathrm{Ca}(\mathrm{OH}) 2 \mathrm{más}$ clorhexidina fue similar a la del $\mathrm{Ca}(\mathrm{OH}) 2$ solo en ocho artículos, mientras que en tres estudios se informó un mejor efecto antibacteriano. La combinación con ciprofloxacina fue más eficaz que el uso de $\mathrm{Ca}(\mathrm{OH}) 2$ solo en el único estudio que probó este antibiótico. En dientes con periodontitis apical asintomática, la eficacia de la combinación de agentes antimicrobianos con $\mathrm{Ca}(\mathrm{OH}) 2$ fue similar a la del $\mathrm{Ca}(\mathrm{OH}) 2$ solo.

Palabras clave: Hidróxido de calcio; Periodontitis apical; Eficacia antibacteriana; Revisión sistemática.

\section{Introduction}

Treatment of the root canal system is essentially aimed at eliminating bacteria and their products in order to prevent or control infections of pulp and periapical tissues (Peters, et al., 1995; Siqueira \& Lopes, 1999). Apical periodontitis is an inflammatory disorder characterized by periapical bone resorption, which has a polymicrobial etiology in which Gramnegative anaerobic bacteria predominate (Santos, et al., 2011; Siqueira, et al., 2011). Chemical-mechanical preparation alone is unable to eliminate all microorganisms from the root canal system (Gazzaneo, et al., 2019). Within this context, several studies demonstrated that no instrument has so far been able to prepare all root canal walls (Belladonna, et al., 2018; Gavini, et al., 2018; Versiani, et al., 2018; Zuolo, et al., 2018; De Deus, et al., 2019; Zhao, et al., 2019; Velozo, et al., 2020). Although cleaning and chemical-mechanical preparation are effective in reducing bacterial counts, bacteria may persist inside the complex anatomy of the root canal system, increasing the risk of treatment failure (Byström \& Sundqvist, 1981; Vianna et al. 2008). Antimicrobial intracanal medicaments are therefore recommended to promote additional bacterial elimination and to increase the success of endodontic treatment (Byström, et al., 1985; Paiva, et al., 2013).

Calcium hydroxide $\left(\mathrm{Ca}(\mathrm{OH})_{2}\right)$ is the most common intracanal medication used in endodontics and is recognized as one of the most effective antimicrobial dressings. This property is attributed to the release of hydroxyl ions, which confer a highly alkaline environment with a $\mathrm{pH}$ of approximately 12.5 (Siqueira \& Lopes, 1999). In addition, $\mathrm{Ca}(\mathrm{OH})_{2}$ is able to dissolve organic matter and to induce mineralization (Camargo, et al., 2006; Mori, et al., 2009). Most of the microorganisms in infected root canals are unable to survive in an alkaline environment (Heithersay, 1975). However, $\mathrm{Ca}(\mathrm{OH})_{2}$ is not equally 
effective against all bacteria found in the root canal system (Ørstavik \& Haapasalo, 1990). Despite its favorable properties, $\mathrm{Ca}(\mathrm{OH})_{2}$ is combined with other compounds such as chlorhexidine, ibuprofen and ciprofloxacin to target resistant bacteria and thus broaden its antimicrobial spectrum (Zerella, et al., 2005; Manzur, et al., 2007; Gondim, et al., 2011; Ferreira, et al., 2015; Freitas, et al., 2017; Karataş, et al., 2020).

However, controversy still exists in clinical practice whether $\mathrm{Ca}(\mathrm{OH})_{2}$ combined with other compounds may indeed improve the removal or elimination of bacteria from infected root canals. Although some studies found additional bacterial elimination after the intracanal application of $\mathrm{Ca}(\mathrm{OH})_{2}$ (Byström, et al., 1985; Shuping, et al., 2000; McGurkin-Smith, et al., 2005), others reported an increase in the proportion of positive cultures and bacterial counts (Peters, et al., 2002; Waltimo, et al., 2005). Chlorhexidine emerged as a potential intracanal medication (Gomes, et al., 2003; Siqueira, et al., 2007; Vianna, et al., 2007; Tavares, et al., 2013) and its use alone or in combination with $\mathrm{Ca}(\mathrm{OH})_{2}$ paste has been suggested. Although studies have investigated the antibacterial property of $\mathrm{Ca}(\mathrm{OH})_{2}$, including the combination with chlorhexidine, the information about its effects on the periapical immune response is still incipient (Tavares, et al., 2012, 2013). In addition to chlorhexidine, a laboratory study proposed additives such as nonsteroidal anti-inflammatory drugs and antibiotics to increase the antibacterial effectiveness of $\mathrm{Ca}(\mathrm{OH})_{2}$ but the latter was not affected by these additives (de Freitas, et al., 2017). However, a recent clinical study indicated greater antibacterial effectiveness of the use of $\mathrm{Ca}(\mathrm{OH})_{2}$ combined with ciprofloxacin as intracanal medication in vivo (Karataş, et al., 2020).

There is an expressive number of randomized clinical trials, but no systematic review has synthesized the data of all of these studies to provide a more effective response. Therefore, the aim of this systematic review was to compare the clinical performance of $\mathrm{Ca}(\mathrm{OH})_{2}$ as an intracanal medication alone or combined with other antimicrobial agents determined by microbial reduction in microbiological analysis. The null hypothesis was that the antibacterial performance of $\mathrm{Ca}(\mathrm{OH})_{2}$ alone was not better than when combined with other antimicrobial agents.

\section{Material and method}

\section{Protocol and registration}

The present systematic review followed the Preferred Reporting Items for Systematic Reviews and Meta-Analyses (PRISMA) guidelines (Moher, et al., 2015) and was registered in the International Prospective Register of Systematic Reviews (PROSPERO) (CRD 42020205741).

\section{Eligibility criteria}

The following research question was formulated according to the PICO model (population, intervention, comparison, and outcome): Is the antibacterial effectiveness of $\mathrm{Ca}(\mathrm{OH})_{2}$ paste as an intracanal medication combined with other drugs greater than that of calcium hydroxide paste alone in apical periodontitis? According to these criteria, the population consisted of patients with apical periodontitis. As the intervention, treatment with $\mathrm{Ca}(\mathrm{OH})_{2}$ paste combined with chlorhexidine, antiinflammatory drugs and antibiotics was compared to treatment with $\mathrm{Ca}(\mathrm{OH})_{2}$ paste alone. The primary outcome evaluated in the present study was antibacterial effectiveness.

The following studies were considered eligible for the present review: 1) randomized clinical trials, 2) nonrandomized intervention studies, 3) studies including a minimum of 10 patients, 4) studies comparing the use of $\mathrm{Ca}(\mathrm{OH})_{2}$ alone and in combination with other compounds, 5) studies evaluating primary and permanent teeth with apical periodontitis, and 6) studies including teeth not submitted to retreatment. Exclusion criteria were: 1) retrospective studies, 2) case reports, 3) case 
series, 4) in vitro studies, 5) in vivo (animal) studies, 6) literature reviews, and 7) studies including teeth previously submitted to root canal treatment.

\section{Search strategy and data sources}

Two independent reviewers (C.V. and C.A.A.L.) performed the systematic search in the following electronic databases without publication date restrictions: PubMed/MEDLINE, Web of Science and Cochrane Library. The following search terms were used: (((Intracanal OR Apical Periodontitis OR Periradicular lesions OR Endodontic Infections OR Periapical lesions) AND (Calcium Hydroxide OR CaOH2)) AND (Associated OR Association OR Mixture OR Combined OR Combination OR Chlorhexidine OR Ibuprofen OR Ciprofloxacin)) AND (Antibacterial OR Effectiveness OR Microbiological OR Microbiology OR Disinfection).

After the removal of duplicates, the studies were selected from each database based on the title and abstract. In addition, the reference lists of the included studies and previous reviews were hand searched to identify potential articles for inclusion. The two reviewers (C.V. and C.A.A.L.) also hand searched specific journals such as the International Endodontic Journal and Journal of Endodontics for articles published until August 2020. Disagreements between the authors were resolved through discussion with a third reviewer (D.S.A.) until consensus was reached. The Rayyan reference manager (Qatar Computing Research Institute, Doha, Qatar) (Ouzzani et al. 2016) was used for the search and selection of the articles. For inclusion, the full text of all selected articles was read.

\section{Data extraction and analysis}

Qualitative and quantitative data were extracted from the articles by one of the reviewers (C.V.) and a second reviewer (C.A.A.L.) verified all data. Discrepancies between reviewers were resolved by consensus-based discussion with a third reviewer (D.S.A.). The kappa test was used in an additional analysis to determine the level of agreement between examiners in terms of the titles and abstracts retrieved from the databases.

The following data were extracted from each article: study design, age, sample size per group, number of canals, type of tooth receiving the intervention, diagnosis prior to treatment, drug combinations with $\mathrm{Ca}(\mathrm{OH})_{2}$, method for the assessment of bacterial reduction, duration of intracanal medication, number of samples, and bacterial count obtained by microbiological analysis. The main authors were contacted for missing data.

\section{Risk of bias and quality of the included studies}

The Cochrane risk-of-bias tool for randomized clinical trials (RoB 2.0) (Higgins, et al., 2018) was used to assess the internal validity (risk of bias) of the included studies. The set of questions and algorithms of RoB 2.0 were followed to judge the risk of bias for individual domains as low risk, high risk, or some concerns.

\section{Results}

The database search retrieved 986 articles, including 625 from PubMed/MEDLINE, 267 from Web of Science, and 94 from the Cochrane Library. After the removal of 214 duplicates, 772 articles remained. All titles and abstracts were reviewed and 758 studies were excluded. After full-text reading of the 14 articles, two studies (Uluköylü, et al., 2019; Zerella, et al., 2005) were excluded because the samples included teeth submitted to retreatment. The detailed search strategy is shown in the flow chart (Figure 1). The kappa coefficient for interexaminer agreement was 0.88 for PubMed/MEDLINE, Web of Science and Cochrane Library, demonstrating a high level of agreement between reviewers. 
Figure 1. Flow chart showing the article selection process.
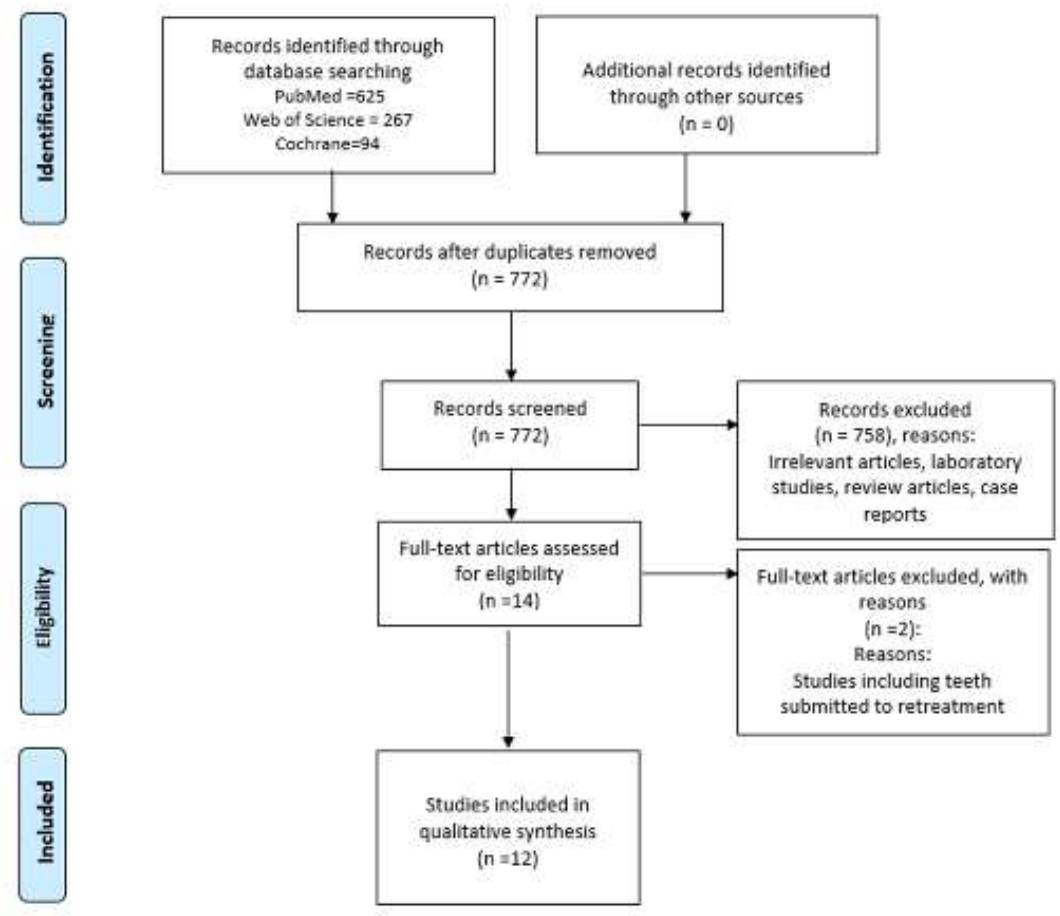

Source: Authors.

Twelve articles were selected for analysis of the data. All selected studies were randomized clinical trials published between 2006 and 2020. The studies included 499 patients; there were 172 patients with primary teeth aged 2 to 8 years (mean of 5 years) and 205 patients with permanent teeth aged 10 to 65 years (mean of 34.28 years). Three studies did not report the age of the patients, totaling 122 patients (Ferreira, et al., 2015; Martinho, et al., 2015; Martinho, et al., 2018). Four of these studies investigated primary teeth (Onçag, et al., 2006; Gondim, et al., 2011; Silva, et al., 2017; Dutta, et al., 2017). All studies carried out agar cultures of microbiological samples obtained from the root canal after medication removal and determined the number of colony-forming units (CFU). Other microbiological methods were also used: turbidity measurement (Manzur, et al., 2007), quantification of endotoxins (Vianna, et al., 2007; Martinho, et al., 2018), DNA-DNA hybridization (checkerboard DNA-DNA hybridization technique) (Vianna, et al., 2008; Ferreira, et al., 2015), real time quantitative PCR (qRT-PCR) analysis (Gondim, et al., 2011; Karataş, et al., 2020), and quantification of inflammatory cytokines (Martinho, et al., 2015; Martinho, et al., 2018). Calcium hydroxide was combined with chlorhexidine, ibuprofen and ciprofloxacin in the included studies; the latter two were only used in the study of Karatas, et al. (2020). The effectiveness of $\mathrm{Ca}(\mathrm{OH})_{2}$ combined with chlorhexidine was similar to that of $\mathrm{Ca}(\mathrm{OH})_{2}$ alone in eight articles (Manzur, et al., 2007; Vianna, et al., 2007; Vianna, et al., 2008; Gondim, et al., 2011; Ferreira, et al., 2015; Silva, et al., 2017; Martinho, et al., 2015; Martinho, et al., 2018). The combination of $\mathrm{Ca}(\mathrm{OH})_{2}$ and chlorhexidine showed better antimicrobial activity in three studies (Onçag, et al., 2006; Sinha, et al., 2013; Dutta, et al., 2017). The combination with ciprofloxacin was better than the use of $\mathrm{Ca}(\mathrm{OH})_{2}$ alone in the only study that tested this antibiotic (Karataş, et al., 2020). The characteristics of the studies are described in Table 1. 
Table 1. The characteristics of the studies.

\begin{tabular}{|c|c|c|c|c|c|c|c|c|c|}
\hline Author/year & $\begin{array}{l}\text { Group } \\
\text { (n) }\end{array}$ & $\begin{array}{l}\text { No, of } \\
\text { patients }\end{array}$ & $\begin{array}{l}\text { Age } \\
\text { (years) }\end{array}$ & $\begin{array}{l}\text { Type of } \\
\text { tooth }\end{array}$ & $\begin{array}{l}\text { Number of } \\
\text { canals }\end{array}$ & $\begin{array}{l}\text { Combination } \\
\text { with } \mathrm{Ca}(\mathrm{OH}) a\end{array}$ & Microbiological method & $\begin{array}{l}\text { Duration of } \\
\text { intracanal } \\
\text { medication }\end{array}$ & Best effect \\
\hline $\begin{array}{l}\text { Onçag et al } \\
2006\end{array}$ & 32 & 56 & $4-6$ & $\begin{array}{l}\text { Primary } \\
\text { upper }\end{array}$ & Single canal & $\begin{array}{l}1 \% \mathrm{CHX} \\
\text { gluconate gel }\end{array}$ & Culture on blood agar & 2 days & Combination \\
\hline $\begin{array}{l}\text { Manzur et al } \\
2007\end{array}$ & 11 & 33 & $10-54$ & PMM/MM & $\begin{array}{l}\text { Single or } \\
\text { multiple } \\
\text { canals }\end{array}$ & $2 \%$ liquid $\mathrm{CHX}$ & $\begin{array}{l}\text { Culture on blood agar and } \\
\text { turbidity meastement }\end{array}$ & 7 days & Similar \\
\hline $\begin{array}{l}\text { Vianna et al. } \\
2007\end{array}$ & 8 & 24 & $18-65$ & NR & $\begin{array}{l}\text { Single root, } \\
\text { single canal }\end{array}$ & $2 \%$ CHX gel & $\begin{array}{l}\text { Culture on blood agar and } \\
\text { quantitative chromogenic LAL. } \\
\text { assay (endotoxins) }\end{array}$ & 7 days & Similar \\
\hline $\begin{array}{l}\text { Vianna et al. } \\
2008\end{array}$ & 8 & 24 & $18-59$ & NR & $\begin{array}{l}\text { Single root, } \\
\text { single canal }\end{array}$ & $2 \% \mathrm{CHX}$ gel & $\begin{array}{l}\text { Culture on blood agar and } \\
\text { DNA-DNA bybridization }\end{array}$ & 7 days & Similar \\
\hline $\begin{array}{l}\text { Gondim et al. } \\
2011\end{array}$ & $\begin{array}{l}\text { G I: } 6 \\
\text { GII: } \\
10\end{array}$ & 28 & $2-8$ & Primary & NR & $2 \% \mathrm{CHX}$ gel & qRT-PCR & 30 days & Similar \\
\hline $\begin{array}{l}\text { Sinha et al } \\
2013\end{array}$ & 10 & 79 & $15-50$ & Permaneat & NR & $246 \mathrm{CHX}$ gel & Culture on blood agar & 7 days & Combination \\
\hline $\begin{array}{l}\text { Ferreira et al. } \\
2015\end{array}$ & 10 & 20 & NR & NR & Single canal & $2 \% \mathrm{CHX}$ gel & $\begin{array}{l}\text { Culture on blood agar and } \\
\text { DNA-DNA bybridization }\end{array}$ & 14 day 5 & Similar \\
\hline $\begin{array}{l}\text { Martinhe et al. } \\
2015\end{array}$ & 10 & 30 & NR & NR & Single canal & $2 \% \mathrm{CHX}$ gel & $\begin{array}{l}\text { Culture on biood agar and } \\
\text { quantification of inflammatory } \\
\text { cytokines }\end{array}$ & 14 days & Similar \\
\hline Silva et al: 2017 & 20 & 40 & 3.7 & $\begin{array}{l}\text { Primary } \\
\text { (MIMM) }\end{array}$ & NR & $\mathrm{CHX}$ gel & Culture on blood agar & 30 days & Similar \\
\hline Dutta et al. 2017 & $\begin{array}{l}\text { G I: } 9 \\
\text { G II: } \\
10\end{array}$ & 48 & $4-6$ & $\begin{array}{l}\text { Primary } \\
\text { IMLM }\end{array}$ & NR & $2 \% \mathrm{CHX}$ gel & Culture on blood agar & 7 days & Combination \\
\hline $\begin{array}{l}\text { Martinhe et al. } \\
2018\end{array}$ & 12 & 72 & $\mathrm{NR}$ & $\begin{array}{l}\text { MI } \\
\text { IPMM } \\
\text { 2PMM }\end{array}$ & $\mathrm{NR}$ & $2 \%$ CHX gel & $\begin{array}{l}\text { Culture on blood agar, } \\
\text { quantitative cluomogenic LAL. } \\
\text { assay (endotoxins), and } \\
\text { ELISA (inflammatory } \\
\text { cytokines) }\end{array}$ & 7 and 14 days & Similar \\
\hline $\begin{array}{l}\text { Karata; et al. } \\
2020\end{array}$ & 15 & 45 & $17-49$ & $\begin{array}{l}\text { Permaneat } \\
\text { incisors } \\
\text { and canines }\end{array}$ & Single canal & $\begin{array}{l}\text { lbuprofen or } \\
\text { ciproflexacin }\end{array}$ & $Q R T \cdot P C R$ & 7 days & $\begin{array}{l}\text { Combined with } \\
\text { ciprotloxacin }\end{array}$ \\
\hline
\end{tabular}

Source: Authors.

The RoB 2.0 tool (Higgins, et al., 2018) was used to assess the quality of the included studies and the results are summarized in Table 2. Regarding the overall risk of bias in the studies, the risk of bias was low in three articles (Gondim, et al., 2011; Silva, et al., 2017; Karataş, et al., 2020). Eight studies were classified as having some concerns (Onçag, et al., 2016; Manzur, et al., 2007; Vianna, et al., 2007; Vianna, et al., 2008; Ferreira, et al., 2015; Martinho, et al., 2015; Martinho, et al., 2018; Dutta, et al., 2017). Only one study was classified as high risk of bias (Sinha, et al., 2013). The randomization method was reported in only two of the selected studies (Silva, et al., 2017; Karataş, et al., 2020). Based on the information about randomization, one study classified as a double-blind clinical trial, although it did not report the method, was considered to be low risk of bias (Gondim, et al., 2011). Nine studies (Onçag, et al., 2016; Manzur, et al., 2007; Vianna, et al., 2007; Vianna, et al., 2008; Sinha, et al., 2013; Ferreira, et al., 2015; Martinho, et al., 2015; Martinho, et al., 2018; Dutta, et al., 2017) did not provide sufficient information about the use of a random allocation sequence or allocation concealment and were classified as having some concerns. There were some concerns in three studies (Sinha, et al., 2013; Onçag, et al., 2016; Dutta, et al., 2017) because of the lack of information about the intervention. The study of Sinha et al. (2013) was classified as high risk of bias because of the lack of a complete sampling frame of eligible individuals and problems with randomization. 
Table 2. Risk of bias assessment using RoB 2.

\begin{tabular}{|c|c|c|c|c|c|c|c|c|c|c|c|c|}
\hline Evaluation & $\begin{array}{l}\text { Onçag et } \\
\text { al. } 2006\end{array}$ & $\begin{array}{l}\text { Manzur } \\
\text { et al. } \\
2007\end{array}$ & $\begin{array}{l}\text { Vianna } \\
\text { et al. } \\
2007\end{array}$ & $\begin{array}{l}\text { Viann } \\
\text { a et } \\
\text { al. } \\
2008\end{array}$ & $\begin{array}{l}\text { Gondim } \\
\text { et al. } \\
2011\end{array}$ & $\begin{array}{l}\text { Sinha } \\
\text { et al. } \\
2013\end{array}$ & $\begin{array}{l}\text { Ferreira } \\
\text { et al. } \\
2015\end{array}$ & $\begin{array}{l}\text { Silva et } \\
\text { al. } \\
2017\end{array}$ & $\begin{array}{l}\text { Martinho } \\
\text { et al. } 2015\end{array}$ & $\begin{array}{l}\text { Martinh } \\
\text { o et al. } \\
2018\end{array}$ & $\begin{array}{l}\text { Dutta } \\
\text { et al. } \\
2017\end{array}$ & $\begin{array}{l}\text { Karatas } \\
\text { et al. } \\
2020\end{array}$ \\
\hline \multicolumn{13}{|l|}{$\begin{array}{l}\text { R Bias arising } \\
\text { from the } \\
\text { randomisation } \\
\text { process }\end{array}$} \\
\hline \multicolumn{13}{|l|}{$\begin{array}{l}\text { D Bias due to } \\
\text { deviations from } \\
\text { intended } \\
\text { interventions }\end{array}$} \\
\hline \multicolumn{13}{|l|}{$\begin{array}{l}\text { Mi Bias due to } \\
\text { missing outcome } \\
\text { data }\end{array}$} \\
\hline \multicolumn{13}{|l|}{$\begin{array}{l}\text { S Bias in selection } \\
\text { of the reported } \\
\text { result }\end{array}$} \\
\hline $\begin{array}{l}\text { O Overall risk of } \\
\text { bias } R\end{array}$ & & & & & & & & & & & & \\
\hline
\end{tabular}

Source: Authors.

\section{Discussion}

Based on the results obtained, the null hypothesis of this review was accepted. Most of the studies (Manzur, et al., 2007; Vianna, et al., 2007; Vianna, et al., 2008; Gondim, et al., 2011; Ferreira, et al., 2015; Silva, et al., 2017; Martinho, et al., 2015; Martinho, et al., 2018) demonstrated similar effectiveness for the use of $\mathrm{Ca}(\mathrm{OH})_{2}$ alone and combined with other antimicrobial agents. Chlorhexidine was the most frequently used agent in these studies. Only Karataş, et al. (2020) studied ciprofloxacin combined with $\mathrm{Ca}(\mathrm{OH})_{2}$ and found that the combination was more effective than $\mathrm{Ca}(\mathrm{OH})_{2}$ alone. In a systematic review that included in vitro, in vivo and ex vivo studies (Saatchi, et al., 2014), the authors concluded that mixing $\mathrm{Ca}(\mathrm{OH})_{2}$ with chlorhexidine does not significantly increase the antimicrobial activity of the former against E. faecalis. Mohammadi \& Abbott (2009) reported that the benefits of combining $\mathrm{Ca}(\mathrm{OH})_{2}$ and chlorhexidine in an intracanal paste remain obscure and controversial. Currently, the scenario of antimicrobial combinations with $\mathrm{Ca}(\mathrm{OH})_{2}$ does not seem to have resolved this clinical doubt. In a systematic review, Sathorn et al. (2007) concluded that $\mathrm{Ca}(\mathrm{OH})_{2}$ has limited activity in eliminating bacteria from the root canal. This assumption has encouraged researchers to identify new combinations. Within this context, the study of Karataş et al. (2020) is a guide for future clinical trials, in which the authors used a nonsteroidal anti-inflammatory drug (ibuprofen) and an antibiotic (ciprofloxacin). This is the only clinical trial that evaluated these combinations based on the in vitro study of Freitas et al. (2017), in which there was an the increased antibacterial effectiveness of $\mathrm{Ca}(\mathrm{OH})_{2}$.

Eleven of the 12 included studies used chlorhexidine combined with $\mathrm{Ca}(\mathrm{OH})_{2}(\mathrm{Onçag}$, et al., 2006; Manzur, et al., 2007; Vianna, et al., 2007; Vianna, et al., 2008; Gondim, et al., 2011; Sinha, et al., 2013; Ferreira, et al., 2015; Silva, et al., 2017; Martinho, et al., 2015; Martinho, et al., 2018; Dutta, et al., 2017). The concentrations of chlorhexidine in these studies ranged from 1 to 2\%. Eight of the 11 studies using this combination (Manzur, et al., 2007; Vianna, et al., 2007; Vianna, et al., 2008; Gondim, et al., 2011; Ferreira, et al., 2015; Silva, et al., 2017; Martinho, et al., 2015; Martinho, et al., 2018) reported 
similar effectiveness compared to $\mathrm{Ca}(\mathrm{OH})_{2}$ alone. According to Mohammadi \& Abbott (2009), different factors might explain this lack of additional antibacterial activity of chlorhexidine; for example, the antibacterial activity of chlorhexidine is $\mathrm{pH}$ dependent, with the ideal $\mathrm{pH}$ ranging from 5.5 to 7.0. Thus, chlorhexidine is unstable at alkaline $\mathrm{pH}$ and tends to precipitate. In addition, chlorhexidine can interact with dentin components, a fact that also limits its action. In vitro studies have shown that the interaction of calcium, sodium lauryl sulfate and urea can reduce the antimicrobial activity of chlorhexidine (Kuruvilla, et al., 1998). In this respect, the antibacterial efficacy of the combination of $\mathrm{Ca}(\mathrm{OH})_{2}$ with chlorhexidine is lower due to precipitation that occurs at high $\mathrm{pH}$ (Gomes, et al., 2006).

The 12 studies carried out microbiological cultures on agar for the quantification of CFU, in addition to turbidity measurement (Manzur, et al., 2007), quantification of endotoxins (Vianna, et al., 2007; Martinho, et al., 2018), DNA-DNA hybridization (checkerboard DNA-DNA hybridization technique) (Vianna, et al., 2008; Ferreira, et al., 2015), qRT-PCR (Gondim, et al., 2011; Karataş, et al., 2020), and quantification of inflammatory cytokines (Martinho, et al., 2015; Martinho, et al., 2018). The different microbiological methods in these randomized clinical trials cannot be compared and a meta-analysis is therefore difficult because of the heterogeneity of the data, as well as the particularities and limitations of each test. For example, qPCR is more sensitive in detecting small numbers of difficult-to-culture microorganisms and bacteria (Siqueira \& Roças 2005); however, this method also detects DNA of dead cells.

Among the 11 studies that investigated the combination of chlorhexidine and $\mathrm{Ca}(\mathrm{OH})_{2}$, one reported chlorhexidine combined or not with $\mathrm{Ca}(\mathrm{OH})_{2}$ to be more effective than $\mathrm{Ca}(\mathrm{OH})_{2}$ alone against $\mathrm{E}$. faecalis in necrotic canals of primary teeth under in vivo conditions (Onçag, et al., 2006) and another found chlorhexidine combined or not with $\mathrm{Ca}(\mathrm{OH})_{2}$ to be more effective than $\mathrm{Ca}(\mathrm{OH})_{2}$ alone against all microorganisms tested (Sinha, et al., 2013). These studies used sterile distilled water (Onçag, et al., 2006) and sterile saline (Sinha, et al., 2013) as irrigant. The latter study was the only one classified as high risk of bias in the present systematic review. In the study by Onçag, et al. (2006), the intracanal medication remained for only 48 hours before the third microbiological sampling. Dutta, et al. (2017) found that the use of $\mathrm{Ca}(\mathrm{OH})_{2} \mathrm{combined} \mathrm{with}$ chlorhexidine as intracanal medication was more effective than $\mathrm{Ca}(\mathrm{OH})_{2}$ alone. However, the authors did not evaluate the effect of chlorhexidine alone.

The study by Karataş, et al. (2020), the only one that tested ibuprofen and ciprofloxacin in combination with $\mathrm{Ca}(\mathrm{OH})_{2}$, reported that the addition of ciprofloxacin to $\mathrm{Ca}(\mathrm{OH})_{2}$ resulted in additional antibacterial effectiveness in vivo when used as intracanal medication in teeth with asymptomatic apical periodontitis. Ciprofloxacin is a second-generation fluoroquinolone that has few side effects and excellent pharmacokinetic properties, exerting notable antimicrobial activity (Zhang, et al., 2018). Although the success of endodontic treatment depends on a range of factors, the reduction or elimination of infection is one of the most important criteria (Peters, et al., 2002; Ito, et al., 2011). The use of an intracanal medication before root canal obturation increases the predictability and prognosis of endodontic success since it provides complementary antimicrobial activity to complete root canal preparation. The biological effect of any intracanal medication, administered alone or in combination, depends on several factors such as concentration and interaction of the drug, compaction of the medication throughout the root canal, virulence of the microorganisms, and individual operator technique (Dutta, et al., 2017). For these reasons, further studies are needed to elucidate the mechanisms underlying the effect of combinations of antimicrobial agents with $\mathrm{Ca}(\mathrm{OH})_{2}$. The limitations of the present study are due to the fact that some clinical trials did not follow the CONSORT protocol. In addition, the heterogeneity of the studies, including the use of different microbiological techniques and different combinations of antimicrobial agents, impairs their comparison. 


\section{Conclusion}

The effectiveness of the combination of antimicrobial agents with $\mathrm{Ca}(\mathrm{OH})_{2}$ was similar to that of $\mathrm{Ca}(\mathrm{OH})_{2}$ alone, as intracanal medication in teeth with asymptomatic apical periodontitis.

\section{Acknowledgements}

This study was financed in part by the Coordenação de Aperfeiçoamento de Pessoal de Nível Superior - Brasil (CAPES) - Finance Code 001.

\section{References}

Belladonna, F. G., et al. (2018) Micro-computed tomography shaping ability assessment of the new blue thermal treated reciproc instrument. Journal of Endodontics, 44 (7), 1146-50. 10.1016/j.joen.2018.03.008.

Byström, A., et al. (1985) The antibacterial effect of camphorated paramonochlorophenol, camphorated phenol and calcium hydroxide in the treatment of infected root canals. Dental Traumatology, 1(5),170-5. 10.1111/j.1600-9657.1985.tb00652.x.

Byström, A., \& Sundqvist, G. (1981) Bacteriologic evaluation of the efficacy of mechanical root canal instrumentation in endodontic therapy. Scandinavian Journal of Dental Research, 89 (4), 321-8. 10.1111/j.1600-0722.1981.tb01689.x.

Camargo, C. H., et al. (2006) Vehicle influence on calcium hydroxide pastes diffusion in human and bovine teeth. Dental Traumatology, 22(6), 302-6. $10.1111 / \mathrm{j} .1600-9657.2005 .00326 . x$

De Deus, G., et al. (2019) Shaping efficiency as a function of time of a new heat-treated instrument. International Endodontic Journal, 52 (3), 337-42. 10.1111/iej.13000.

Dutta, B., et al. (2017) Evaluation ofAntimicrobial Efficacy of various Intracanal Medicaments in Primary Teeth: An in vivo Study. International Journal of Clinical Pediatric Dentistry, 10 (3), 267-71. 10.5005/jp-journals-10005-1448.

Freitas, R. P., et al. (2017) Efect of the association of nosteroidal anti-inflammatory and antibiotic drugs on antibiofilm activity and pH of calcium hydroxide pastes. Journal of Endodontics 43, 131-4.

Ferreira, N. S., et al. (2015) Microbiological profile resistant to different intracanal medications in primary endodontic infections Journal of Endodontics, 41(6), 824-30. 10.1016/j.joen.2015.01.031.

Gavini, G., et al. (2018) Nickel-titanium instruments in endodontics: a concise review of the state of the art. Brazilian Oral Researc, 32 (suppl 1), 44-65. 10.1590/1807-3107bor-2018.vol32.0067.

Gazzaneo, I., et al. (2019) Root canal disinfection by single- and multiple instrument systems: effects of sodium hypochlorite volume, concentration, and retention time. Journal of Endodontics, 45 (6), 736-4110.1016/j.joen.2019.02.017.

Gomes, B. P., et al. (2003) Evaluation of time required for recontamination of coronally sealed canals medicated with calcium hydroxide and chlorhexidine. International Endodontic Journal, 36 (9), 604-09. 10.1046/j.1365-2591.2003.00694.x.

Gomes, B P., et al. (2006) In vitro evaluation of the antimicrobial activity of calcium hydroxide combined with chlorhexidine gel used as intracanal medicament. Oral Surgery, Oral Medicine, Oral Pathology and Oral Radiology, 102(4), 544-50. 10.1016/j.tripleo.2006.04.010.

Gondim, J O., et al. 2011) Effect of a calcium hydroxide/chlorhexidine paste as intracanal dressing in human primary teethwith necrotic pulp against Porphyromonas gingivalis and Enterococcus faecalis. International Journal of Paediatric Dentistry, 22(2), 116-24. 10.1111/j.1365-263X.2011.01174.X.

Heithersay, G. S. (1975) Calcium hydroxide in the treatment of pulpless teeth with associated pathology. International Endodontic Journal, 8(2), 74-93. 10.1111/j.1365-2591.1975.tb01000.x.

Higgins, J. P. T., et al. (2018) ROB2 Development Group. A revised tool for assessing risk of bias in randomized trials. In: Chandler J, McKenzie J, Boutron I, Welch V, eds. Cochrane Methods. London: Cochrane, pp 1-69.

Ito, I. Y., et al. (2011) Microbial cultureand checkboard DNA-DNA hybridization assessment of bacteria in root canals of primary teeth pre- and postendodontic therapy with calcium hydroxide/chlorhexidine paste. International Journal and Paediatric Dentistry, 21(5), 353-60. 10.1111/j.1365263X.2011.01131.x.

Karatas, E., et al.. (2020) Antibacterial effectiveness of calcium hydroxide alone ou in combination with Ibuprofen and Ciprofloxacin in teeth with asymptomatic apical periodontitis: a randomized clinical study. International Endodontic Journal, 53 (6), 742-53. 10.1111/iej.13277.

Manzur, A., et al. (2007) Bacterial quantification in teeth with apical periodontitis related to instrumentation and diferente intracanal medications: a randomized clinical trial. Journal of Endodontics, 33(2), 114-18.

Martinho, F. C., et al. (2018) Clinical comparison of the effectiveness of 7- and 14-day intracanal medications in root canal disinfection and inflammatory cytokines. Clinical Oral Investigation, 22(1), 523-30. . 10.1007/s00784-017-2143-x. 
Martinho, F. C., et al. (2015) Clinical influence of different intracanal medications on Th1-type and Th2-type cytokine responses in apical periodontitis. Journal of Endodontics, 41(2),169-75. 10.1016/j.joen.2014.09.028.

McGurkin-Smith, R., et al. (2005) Reduction of intracanal bacteria using GT rotary instrumentation, 5.25\% NaOCl, EDTA, and Ca(OH)2. Journal of Endodontics, 31(5), 359-63. 10.1097/01.don.0000145035.85272.7c.

Mohammadi, Z., \& Abbott, P. V. (2009) The properties and applications of chlorhexidine in endodontics. International Endodontic Journal, 42(4), $288-302$. doi:10.1111/j.1365-2591.2008.01540.x.

Moher, D., et al. (2015) Preferred reporting items for systematic review and meta-analysis protocols (PRISMA-P) statement. Systematic Reviews 4(1).

Mori, G. G et al. (2009) Evaluation of the diffusion capacity of calcium hydroxide pastes through the dentinal tubules. Brazilian Oral Research, 23(2), 113-8. doi:10.1590/S1806-83242009000200004.

Mourad, O., et al. (2016) Rayyan - a web and mobile app for systematic reviews. Systematic Reviews 5, 210.

Ørstavik, D., \& Haapasalo M. (1990) Disinfection by endodontic irrigants and dressings of experimentally infected dentinal tubules. Dental Traumatology, 6(4),142-9. 10.1111/j.1600-9657.1990.tb00409.x.

Onçag, O., et al. (2006) Efficacy of various intracanal medicaments against Enterococcus faecalis in primary teeth: an in vivo study. Journal Clinical Pediatric Dentistry, 30(3), 233-7.

Paiva, S. S. M., et al. (2013) Clinical antimicrobial efficacy of Niti Rotary instrumentation with $\mathrm{NaOCl}$ irrigation, final rinse with chlorhexidine and interappointment medication: a molecular study. International Endodontic Journal, 46(3), 225-33. 10.1111/j.1365-2591.2012.02111.x.

Peters, L., et al. (1995) The fate and the role of bactéria left in root dentinal tubules. International Endodontic Journal, 28(2), 95-9. 10.1111/j.13652591.1995.tb00166.x.

Peters, L. B., et al. (2002) Effects of instrumentation, irrigation and dressing with calcium hydroxide on infection in pulpless teeth with periapical bone lesions. International Endodontic Journal, 35 (10), 13-21. 10.1046/j.0143-2885.2001.00447.x.

Saatchi, M., et al. (2014) Antibacterial effect of calcium hydroxide combined with chlorhexidine on Enterococcus faecalis: a systematic review and metaanalysis. Journal of Applied Oral Science, 22(5), 356-65. 10.1590/1678-775720140032.

Santos, A. L., et al. (2011) Comparing the bacterial diversity of acute and chronic dental root canal infections. PLoS One, 6(11), e28088. 10.1371/journal.pone.0028088.

Sathorn, C., et al. (2005) Effectiveness of single- versus multiple-visit endodontic treatment of teeth with apical periodontitis: a systematic review and metaanalysis. International Endodontic Journal,38(6), 47-55. 10.1111/j.1365-2591.2005.00955.x.

Shuping, G. B., et al. (2000) Reduction of intracanal bacteria using nickel-titanium rotary instrumentation and various medications. Journal of Endodontics, 26(12), 751-5. 10.1097/00004770-200012000-00022.

Silva, L. A., et al. (2017) Antibacterial effect of calcium hydroxide with or without chlorhexidine as intracanal dressing in primary teeth with apical periodontitis. Pediatric Dentistry, 39(1), 28-33.

Sinha, N., et al. (2013) Evaluation of antimicrobial efficacy of calcium hydroxide paste, chlorhexidine gel, and a combination of both as intracanal medicament: an in vivo comparative study. Journal Conservative Dentistry, 16(1), 65-70. 10.4103/0972-0707.105302.

Siqueira, J. F. Jr, et al. (2011) Pyrosequencing analysis of the apical root canal microbiota. Journal of Endodontic, 37(11), 1499-03. 10.1016/j.joen.2011.08.012.

Siqueira, J. F. Jr., \& Lopes H. (1999) Mechanisms of antimicrobial activity of calcium hydroxide: a critical review. International Endodontic Journal, 32(5), 361-9. 10.1046/j.1365-2591.1999.00275.x.

Siqueira, J. F. Jr, et al. (2007) Reduction in the cultivable bacterial populations in infected root canals by a chlorhexidine based antimicrobial protocol. Journal of Endodontics, 33(5), 541-47. 10.1016/j.joen.2007.01.008.

Siqueira, J. F., et al. (2005) Exploiting molecular methods to explore endodontic infections: part 1 - current molecular technologies for microbiological diagnosis. Journal of Endodontics, 31(6), 411-23. 10.1097/01.don.0000157989.44949.26.

Slim, K., et al. (2003). Methodological index for non-randomized studies (MINORS): development and validation of a new instrument. ANZ Journal of Surgery, 73(9), 712-16. 10.1046/j.1445-2197.2003.02748.x.

Tavares, W. L., et al. (2012) Effects of calcium hydroxide on cytokine expression in endodontic infections. Journal of Endodontics, 38(10),1368- 71. 10.1016/j.joen.2012.06.036.

Tavares, W. L., et al. (2013) The impact of chlorhexidine-based endodontic treatment on periapical cytokine expression in teeth. Journal of Endodontics, 39(7), 889-92. 10.1016/j.joen.2013.02.005.

Velozo, C., et al. (2020) Shaping ability of XP-endo Shaper and ProTaper Next in long oval-shaped canals: a micro-computed tomography study. International Endodontic Journal, 53(7), 998-1006. 10.1111/iej.13301.

Versiani, M. A., et al. (2018) Micro-computed Tomographic Evaluation of the Shaping Ability of XP-endo Shaper, iRaCe, and EdgeFile Systems in Long Oval-shaped Canals. Journal of Endodontics, 44(3), 489-95. 10.1016/j.joen.2017.09.008. 
Research, Society and Development, v. 10, n. 4, e55810414593, 2021

(CC BY 4.0) | ISSN 2525-3409 | DOI: http://dx.doi.org/10.33448/rsd-v10i4.14593

Vianna, M. E., et al. (2008) Comparative analysis of endodontic pathogens using checkerboard hybridization in relation to culture. Oral Microbiology and Immunology, 23(4), 282-90. doi.org/10.1111/j.1399-302X.2007.00425.x

Vianna, M. E., et al. (2007) Effect of root canal procedures on endotoxins and endodontic pathogens. Oral Microbiology and Immunology, 22(6), 411-18. 10.1111/j.1399-302X.2007.00379.x.

Waltimo, T., et al. (2005) Clinical efficacy of treatment procedures in endodontic infection control and one year follow-up of periapical healing. Journal of Endodontics, 31(12), 863-6. doi:10.1097/01.don.0000164856.27920.85.

Zerella, J. A., et al. (2005) Effectiveness of a calcium hydroxide and chlorhexidine digluconate mixture as disinfectant during retreatment of failed endodontic cases. Oral Surgery, Oral Medicine, Oral Pathology, Oral Radiology, and Endodontology 100 (6), 756-61. 10.1016/j.tripleo.2005.05.072.

Zhao, Y., et al. (2019) Evaluation of several instrumentation techniques and irrigation methods on the percentage of untouched canal wall and accumulated dentine debris in C-shaped canals. International Endodontic Journal, 52(9), 1354-65. 10.1111/iej.13119.

Zhang, G-F., et al. (2018) Ciprofloxacin derivatives and their antibacterial activities. European Journal of Medicinal Chemistry, 146, 599-612. 10.1016/j.ejmech.2018.01.078.

Zuolo, M. L., et al. (2018) Micro-CT assessment of the shaping ability of four root canal instrumentation systems in oval-shaped canals. International Endodontic Journal, 51(5), 564-71. 10.1111/iej.12810. 